\title{
Pengaruh Penerapan Good Corporate Governance Terhadap Profitabilitas Pada Perusahaan Perbankan yang terdaftar di BEI Periode 2009-2013
}

\author{
Oleh: \\ Riana Christel Tumewu \\ Stanly W. Alexander \\ Program Pendidikan Profesi Akuntansi \\ Fakultas Ekonomi dan Bisnis \\ Universitas Sam Ratulangi Manado \\ Email : n4n427itel_pooh@yahoo.co.id
}

\begin{abstract}
ABSTRAK
Sejak krisis ekonomi tahun 1997 pelaksanaan tata kelola perusahaan yang baik, atau lebih dikenal dengan Good Corporate Governance (GCG) menjadi isu yang mengemuka di Indonesia. Akibat buruknya tata kelola perusahaan di Indonesia pada masa itu, menyebabkan perekonomian jatuh. Sehingga setiap orang setuju untuk mengcover kesulitan indonesia dimulai dengan tata kelola perusahaan. Objek dari penelitian ini yaitu dampak dari penerapan good corporate governance terhadap ROE. Tujuan dari penelitian ini adalah untuk mengetahui tentang pengaruh penerapn good corporate governance pada kinerja keuangan perusahaan. Sampel dalam penelitian ini adalah perusahaan sektor perbankan yang terdaftar di BEI (Bursa Efek Indonesia) dalam periode 2009-2013. Jumlah sampel yang digunakan sebanyak 16 perusahaan yang diambil melalui purposive sampling. Metode analisis dari penelitian ini menggunakan regresi berganda dan regresi sederhana program SPSS 20.

Kata Kunci: Good Corporate Governance, Profitabilitas
\end{abstract}

\begin{abstract}
Since the economic crisis 1997 the implementation of good corporate governance being an issue in indonesia. The bad thing of governance's company in those days causing indonesian economy being slump. So, every one agree to recovered from adversity, indonesia have to start with governance good corporate. The main objective of this research was to determine the effect of implementation of good corporate governance $(G C G)$ to return on equity. The purpose of this research is to know about the influence of empirical evidence of Good Corporate Governance practices to the company's financial performance. The independent variable in this research is the implementation of GCG and the dependent variable is the financial performance using a ratio of profitability. The sample in this study were banking sector companies listed in Indonesian Stock Exchange (IDX) in the periode 2009-2013. The number of sample used were 16 companies listed were taken by purposive sampling. The method of analysis of this research used simple regression with SPSS 20 Program.

Keyword: Good Corporate Governance, Profitability
\end{abstract}




\section{Latar Belakang}

Sejak tahun 1997 terdapat salah satu faktor penyebab kritis yang melanda Asia termasuk Indonesia yang menyebabkan kebangkrutan perusahaan-perusahaan adalah lemahnya Tata Kelola Perusahaan (TKP). Lemahnya penerapan TKP antara lain adalah semakin terpisahnya antara hubungan para pemegang saham dengan manajemen, kurang transparan perusahaan mengenai kinerja keuangan, semakin tidak terkendalinya pengelolaan dan pengembalian keputusan perusahaan yang terkait dengan kelangsungan hidup perusahaan, dan tidak efektinya komite audit.

Krisis perbankan di Indonesia yang dimulai pada akhir tahun 1997 bukan semata-mata diakibatkan oleh krisis ekonomi, tetapi juga di akibatkan oleh belum di implementasikannya good corporate governance dan etika yang melandasinya. Banyak penyebab utama kegagalan bank yaitu salah satunya dengan adanya manajemen bank yang buruk, karena berani mengambil risiko, dan kurangnya pengawasan yang dilakukan terhadap tindak penipuan dan penggelapan dana. Oleh karena itu, usaha mengembalikan kepercayaan kepada dunia perbankan Indonesia melalui restrukturisasi dan rekapitalisasi, hanya dapat mempunyai dampak jangka panjang apabila disertai tiga tindakan penting, yakni: (1) Ketaatan terhadap prinsip kehati-hatian ; (2) Pelaksanaan Good Corporate Governance; (3) Pengawasan yang efektif dari otorisasi pengawasan bank.

Seiring dengan perkembangan pengelolaan perbankan yang ada, fungsi bank menjadi lebih luas,dan memiliki peran sentral dalam perkembangan ekonomi dan bisnis, kepercayaan menjadi faktor utama seseorang dalam mengalokasikan dana yang dimiliki ke dalam bank. Sementara itu masih terdapat bank yang menyalahgunakan kepercayaan tersebut sehingga merugikan pihak nasabah yang menyebabkan kepercayaan nasabah menurun. Salah satu penyebab penyalahgunaan kepercayaan itu terjadi karena kurangnya tata kelola yang baik dalam suatu perusahaan perbankan atau yang biasa kita kenal dengan Good Corporate Governance. Untuk itu Good Corporate Governance (GCG) sangat dibutuhkan dalam membangun kepercayaan masyarakat dan dunia internasional sebagai syarat mutlak bagi dunia perbankan untuk berkembang dengan baik dan sehat.

Menurut Marihot Nasution dan Doddy Setiawan (2007) menyebutkan bahwa Corporate Governance merupakan konsep yang diajukan demi peningkatan kinerja perusahaan melalui supervisi atau monitoring kinerja manajemen dan menjamin akuntabilitas manajemen terhadap stakeholder dengan mendasarkan kerangka peraturan. Adanya penerapan prinsip $G C G$ diharapkan dapat meningkatkan nilai perusahaan yang dicapai jika perusahaan mampu beroperasi dengan memenuhi laba yang ditargetkan. Adapun manfaat dari penerapan $G C G$ salah satunya yaitu meningkatkan produktifitas dan efisiensi perusahaan yang tentu saja berimbas besar terhadap laba perusahaan yang berdampak pada kepercayaan investor.

Secara teoritis perusahaan yang memiliki laba yang semakin besar akan lebih diminati oleh investor karena diharapkan dapat memberikan return yang lebih besar bagi investor apabila mereka melihat dan menganalisa laporan keuangan perusahaan terlebih dahulu. Sehingga sebelum mengambil keputusan untuk melakukan investasi, mereka menghindari segala sesuatu yang dapat menyebabkan kerugian dari investasi. Dengan adanya laba bersih yang baik maka akan berpengaruh pada kinerja perusahaan dilihat dari rasio profitabilitas yang diukur dengan return on equity (ROE). Penulis merasa tertarik dengan latar belakang yang telah diuraikan sehingga melakukan penelitian dengan judul "Pengaruh penerapan Good Corporate Governance terhadap profitabilitas pada perusahaan perbankan yang terdaftar di BEI 2009-2013"

\subsection{Rumusan Masalah}

Berdasarkan uraian latar belakang masalah diatas, maka penulis merumuskan masalah sebagai berikut.

Apakah penerapan good corporate governance berpengaruh terhadap rasio profitabilitas?

\subsection{Tujuan Penelitian}


Berdasarkan rumusan masalah di atas, maka tujuan penelitian ini adalah untuk mengetahui pengaruh penerapan good corporate governance terhadap rasio profitabilitas.

\section{TINJAUAN PUSTAKA}

\subsection{Teori Good Corporate Governance}

Dua teori utama yang terkait dengan corporate governance adalah stewardship theory dan agency theory. Stewardship theory dibangun di atas asumsi filosofis mengenai sifat manusia, yaitu bahwa manusia pada hakekatnya dapat dipercaya, mampu bertindak dengan penuh tanggungjawab, memiliki integritas dan kejujuran terhadap pihak lain. Dengan kata lain, stewardship theory memandang manajemen sebagai dapat dipercaya untuk bertindak dengan sebaik-baiknya bagi kepentingan publik maupun stakeholder.

Sementara itu, dalam teori keagenan (agency theory), hubungan agensi muncul ketika satu orang atau lebih (principal) memperkerjakan orang lain (agent) untuk memberikan suatu jasa dan kemudian mendelegasikan wewenang pengambilan keputusan kepada agent tersebut.

\subsection{Kerangka Pemikiran}

Berdasarkan latar belakang penelitian dan tinjauan pustaka, dapat diketahui bahwa GCG merupakan suatu sistem yang mengatur bagaimana organisasi dioperasikan dan dijalankan dengan baik karena $G C G$ sebagai sarana interaksi yang mengatur antar struktur dan mekanisme yang menjamin adanya kontrol, namun tetap mendorong efisiensi dan kinerja perusahaan. Sebuah perusahaan akan mengalami peningkatan kinerja jika menerapkan $G C G$. Dalam penelitian ini peneliti tertarik untuk mengukur pengaruh $G C G$ terhadap profitabilitas perusahaan dengan menggunakan rasio $R O E$, sehingga dirumuskan kerangka konseptual penelitian ini sebagai berikut :

\section{Gambar 2.1}

\section{Kerangka Pemikiran Teoritis}

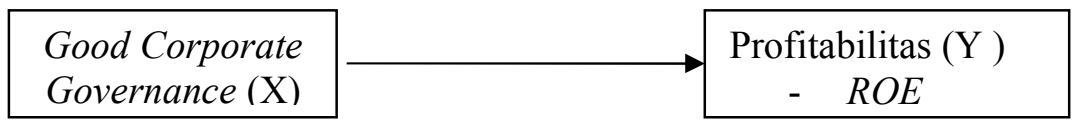

Sumber : Data Olahan (2014)

Penelitian ini menggunakan penerapan $G C G$ yang diukur dengan nilai komposit sebagai variabel independen (variabel $\mathrm{X}$ ) dan profitabilitas perusahaan sebagai variabel dependen (variabel Y), yang diukur dengan menggunakan rasio return on equity (ROE).

\subsection{Hipotesis Penelitian}

Pengaruh Good Coorporate Governance Terhadap Profitabilitas

Profitabilitas adalah kemampuan bank dalam menghasilkan keuntungan atau kemampuan bank dari berbagai sumber daya yang digunakan dalam kegiatan operasional. Sedangkan Rasio Profitabilitas menurut Mamduh M. Hanafi dan Abdul Halim (2005: 85) adalah rasio yang mengukur kemampuan perusahaan menghasilkan keuntungan (profitabilitas) pada tingkat penjualan, asset dan modal saham tertentu. Pada umumnya rasio profitabilitas bank dapat diukur dengan menggunakan beberapa rasio antara lain Return on Asset, Return on Equity, dan Net profit margin.

Menurut Premuroso dan Bhattacharaya (2007) menunjukkan bahwa rasio-rasio yang mampu mewakili profitabilitas perusahaan seperti $R O E$ dan NPM memiliki hubungan positif signifikan dengan $G C G$. Sehingga makin baik pengelolaan perusahaan, maka perusahaan akan makin mampu menghasilkan tingkat imbal hasil yang lebih baik. Berdasarkan pada argumentasi diatas maka peneliti menetapkan hipotesis penelitian yaitu Penerapan $G C G$ berpengaruh terhadap rasio profitabilitas. 
III METODE PENELITIAN

3.1 Populasi dan Sampel Penelitian

Populasi dalam penelitian ini adalah perusahaan yang terdaftar di BEI dari tahun 2009

- 2013. Dari populasi yang ada akan diambil sejumlah tertentu sebagai sampel. Metode pengambilan sampel yang akan digunakan dalam penelitian ini adalah metode purposive sampling. Adapun kriteria-kriteria yang digunakan dalam penelitian sampel adalah:

1. Terdaftar dalam Bursa Efek Indonesia dari tahun 2009 - 2013.

2. Merupakan perusahaan yang telah go public dari tahun 2009-2013.

3. Menerbitkan laporan keuangan lengkap dari tahun $2009-2013$.

4. Laporan keuangan perusahaan disajikan dalam satuan Rupiah (Rp).

5. Penerapan GCG yang diukur dengan menggunakan nilai komposit.

\subsection{Klasifikasi Variabel dan Defenisi Operasional Variabel}

Variabel bebas (Independen Variabel) yang digunakan dalam penelitian ini adalah Penerapan Good Coorporate Governance (X), Sementara variabel terikatnya (Dependen Variabel) adalah rasio profitabilitas yang diproksikan dengan $R O E(\mathrm{Y})$. Berikut ini akan dijelaskan operasionalisasi variabel-variabel yang dikaji dalam penelitian ini.

Good Corporate Governance dalam penelitian ini diukur dengan menggunakan Nilai Komposit Self Assessment GCG. Nilai Komposit Self Assessment GCG merupakan kategori penilaian terhadap pelaksanaan prinsip-prinsip $G C G$, yang berisikan sebelas Faktor Penilaian Pelaksanaan $G C G$ yang telah dijelaskan dalam Tabel 1. Indikator ini diperoleh dari laporan tahunan perusahaan perbankan periode 2009-2013.

Profitabilitas dalam penelitian ini diukur dengan $R O E$, merupakan rasio yang digunakan untuk mengukur kemampuan manajemen bank dalam mengelola modal yang tersedia untuk menghasilkan laba setelah pajak. Semakin besar $R O E$, semakin besar pula tingkat keuntungan yang dicapai bank sehingga modal yang cukup dapat menutupi segala risiko yang mungkin dihadapi bank, rasio ini dihitung menggunakan rumus laba bersih dibahagi modal sendiri. Rasio ini dapat langsung diperoleh dari laporan tahunan perusahaan. 
Tabel 3.2

Operasional Variabel dan Pengukuran Variabel

\begin{tabular}{|c|c|c|c|}
\hline Variabel & Indikator & Ukuran & Skala \\
\hline $\begin{array}{l}\text { Variabel } \\
\text { bebas GCG }\end{array}$ & $\begin{array}{l}\text { Pengukuran } \\
\text { penerapan good } \\
\text { corporate } \\
\text { governance } \\
\text { dilakukan dengan } \\
\text { menggunakan nilai } \\
\text { komposit Self } \\
\text { assesment GCG } \\
\text { yang dipublikasikan } \\
\text { oleh BI. }\end{array}$ & $\begin{array}{l}\text { Nilai komposit Self assesment } \\
G C G \text { dari perusahaan yang diukur } \\
\text { dan dikelompokkan dalam lima } \\
\text { tingkat, } \\
\text { yaitu: } \\
\text { a. Nilai komposit Self assesment } \\
G C G<1,5 \text { menunjukkan kondisi } \\
\text { sangat baik. } \\
\text { b. Nilai komposit Self assesment } \\
G C G \text { 1,5-2,5 menunjukkan } \\
\text { kondisi baik. } \\
\text { c. Nilai komposit Self assesment } \\
G C G \text { 2,3-3,5 menunjukkan } \\
\text { kondisi cukup baik. } \\
\text { d. Nilai komposit Self assesment } \\
G C G \quad 3,5-4,5 \text { menunjukkan } \\
\text { kondisi kurang baik. } \\
\text { e. Nilai komposit Self assesment } \\
G C G 4,5-5 \text { menunjukkan kondisi } \\
\text { tidak baik. }\end{array}$ & $\begin{array}{l}\text { ORDIN } \\
\mathrm{AL}\end{array}$ \\
\hline $\begin{array}{l}\text { Variabel } \\
\text { terikat: } \\
R O E\end{array}$ & $\begin{array}{l}\text { Return on Equity } \\
\text { (ROE) digunakan } \\
\text { untuk mengukur } \\
\text { kemampuan bank } \\
\text { dalam memperoleh } \\
\text { keuntungan bersih } \\
\text { dikaitkan dengan } \\
\text { pembayaran dividen }\end{array}$ & $\begin{array}{l}R O E=\mathrm{LABA} \text { BERSIH/MODAL } \\
\text { SENDIRI }\end{array}$ & RASIO \\
\hline
\end{tabular}

\section{HASIL PENELITIAN DAN PEMBAHASAN}

\subsection{Hasil Penelitian}

\subsubsection{Deskripsi Data Penelitian}

Data yang digunakan dalam penelitian ini adalah data sekunder yang diperoleh dari Bursa efek Indonesia (BEI) berupa Return on Equity dan laporan keuangan yang melaporkan pelaksanaan $G C G$ di bank yang diteliti.

Tabel 4.1

Descriptive Statistics

\begin{tabular}{|l|r|r|r|}
\hline & Mean & \multicolumn{1}{|c|}{$\begin{array}{c}\text { Std. } \\
\text { Deviation }\end{array}$} & $\mathrm{N}$ \\
\hline ROE & 15.7510 & 7.36412 & 80 \\
GCG & 1.5129 & .63176 & 80 \\
\hline
\end{tabular}

Dari table 4.1. diketahui nilai mean untuk ROE sebesar 15.751 Hal ini berarti bahwa jumlah modal yang dimiliki oleh rata- rata bank yang diteliti mampu menghasilkan laba ratarata sebesar 15,75\% dari total modal yang dimiliki tersebut (cukup baik) dan standar deviasi sebesar 7.364 dengan sampel sebanyak 80, sementara nilai mean GCG sebesar 1.51 yang 
berarti nilai komposit yang dimiliki bank yang diteliti mempunyai nilai yang baik dan standar deviasi sebesar 0.631 dengan sampel sebanyak 80 .

\subsubsection{Hasil Pengujian Asumsi Klasik}

Pengujian asumsi klasik dilakukan untuk mengetahui hubungan antara variabel bebas. Berdasarkan hasil pengolahan data yang menggunakan program aplikasi SPSS versi 20, maka diperoleh interpretasi dari hasil pengujian asumsi klasik sebagai berikut:

1. Uji Normalitas

Pengujian Normalitas digunakan untuk menguji apakah dalam sebuah model regresi, variabel terikat, variabel bebas atau keduanya mempunyai distribusi normal ataukah tidak. Model regresi yang baik adalah distribusi data normal atau mendekati normal. Hasil uji Normalitas dapat dilihat pada gambar dibawah :

\section{Gambar 4.1}

\section{Grafik Uji Normalitas}

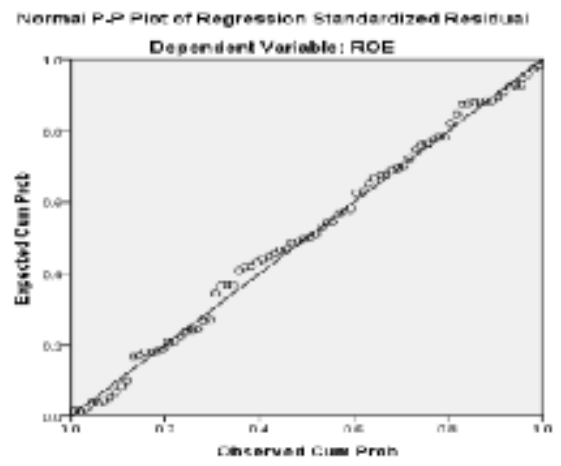

Sumber : Hasil Olahan Data SPSS, 2014

Sebagaimana terlihat dalam grafik Normal P-P plot of regression Standardized Residual, terlihat bahwa titik - titik menyebar disekitar garis diagonal, serta penyebarannya mengikuti arah garis diagonal (membentuk garis lurus ), maka dapat dikatakan bahwa data berdistribusi normal dan model regresi layak dipakai untuk memprediksi profitabilitas berdasarkan variabel bebasnya.

2. Uji Heteroskedastisitas

Untuk mendeteksi ada tidaknya heterokedastisitas dalam penelitian ini, dapat dilihat melalui analisis grafik Scatterplot pada Gambar 4.2.

Gambar 4.2

Hasil Pengujian Heteroskedastisitas

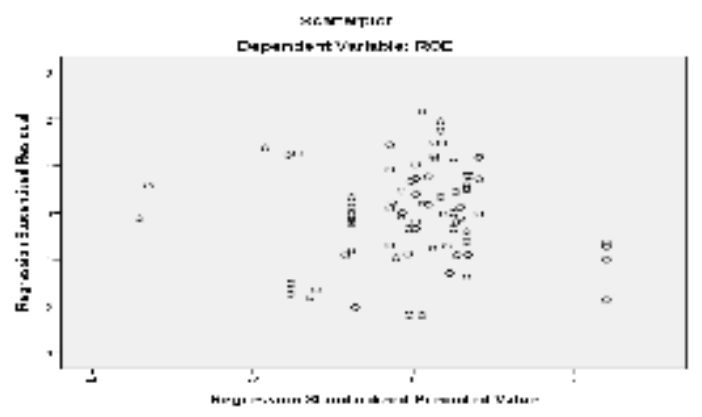


Sumber: Hasil Olahan Data SPSS, 2014

Dari gafik Scatterplot pada Gambar 4.1 terlihat bahwa titik-titik cukup menyebar di atas dan di bawah angka 0 (nol), sehingga dapat disimpulkan bahwa tidak terjadi heteroskedastisitas pada model regresi dalam penelitian ini.

3. Uji Autokorelasi

Model regresi yang baik seharusnya bebas dari autokorelasi. Deteksi adanya autokorelasi yaitu dengan melihat nilai Durbin Watson (DW) pada Tabel 4.2. Nilai DurbinWatson pada Tabel 4.2 adalah 1,624, yang berarti berada di antara -2 dan +2 atau $-2<1,624<$ +2. Maka ini berarti model regresi dalam penelitian ini bebas dari autokorelasi.

Tabel 4.2 Hasil Pengujian Autokorelasi

Model Summary ${ }^{\mathbf{b}}$

\begin{tabular}{|l|r|r|r|r|r|}
\hline Model & R & R Square & $\begin{array}{c}\text { Adjusted R } \\
\text { Square }\end{array}$ & $\begin{array}{c}\text { Std. Error of } \\
\text { the Estimate }\end{array}$ & $\begin{array}{c}\text { Durbin- } \\
\text { Watson }\end{array}$ \\
\hline 1 & $.249^{\mathrm{a}}$ & .062 & .050 & 7.17840 & 1.624 \\
\hline
\end{tabular}

a. Predictors: (Constant), GCG

b. Dependent Variable: ROE

Sumber: Data olahan, 2014

Setelah dilakukan beberapa pengujian asumsi klasik, yaitu uji normalitas, uji heteroskedastisitas, dan uji autokorelasi, maka terbukti bahwa hasil analisa regresi dalam penelitian ini telah bebas dari gangguan normalitas, heteroskedastisitas, dan autokorelasi.

\subsubsection{Hasil Regresi Linear Sederhana}

Hasil analisis regresi linear sederhana yang diperoleh dari pengolahan data menggunakan SPSS 20.0 tampak pada Tabel 4.3. Berdasarkan Tabel 4.3, maka model persamaan regresi linear sederhana dalam penelitian ini adalah sebagai berikut:

Tabel 4.3 Rekapitulasi Hasil Analisis Regresi Sederhana

\begin{tabular}{|l|l|l|l|}
\hline Variabel & \multicolumn{1}{|l|}{$\begin{array}{l}\text { Koefisien Regresi } \\
\text { (B) }\end{array}$} & t & Sig \\
\hline GCG (X) & -2.899 & 2,267 & 0,026 \\
\hline Konstanta & $=20,136$ & \\
R & $=0,249$ & \\
R square & $=0,062$ & \\
Adjusted R & $=0,050$ \\
Square & $=5,141$ & \\
F hitung & $=0,026$ & \\
Signifikansi F & \\
\hline
\end{tabular}

Sumber : Output Analisis Regresi Sederhana

Dari table tersebut dapat diketahui persamaan regresi sederhana adalah,

$$
\mathrm{Y}=20,136-2,899 \mathrm{X}
$$

Keterangan:

$\mathrm{Y} \quad=$ Return On Equity (ROE)

$\mathrm{X}=$ Good Corporate Governance $(G C G)$

Berdasarkan persamaan regresi linear sederhana, dapat dilihat nilai konstanta (a) sebesar 20,136. Hal ini berarti besarnya Return On Equity (ROE) (Y) adalah 20,136 dengan 
asumsi tidak dipengaruhi oleh variabel independent. Koefisien regresi Good Corporate Governance (GCG) (X) sebesar - 2,899 berarti setiap penurunan sebesar 1 satuan yang semakin berkurang nilai GCG berarti semakin baik pengelolaan GCG perusahaan maka, maka akan mengakibatkan peningkatan profitability (return on equity) sebesar 2,899 satuan.

\section{Hasil Pengujian Hipotesis}

Pengaruh Good Corporate Governance (GCG) terhadap Profitability (ROE)

Sesuai hasil uji parsial (uji t) pada Tabel 4.3, diketahui nilai $t_{\text {hitung }}$ dari variabel GCG adalah sebesar 2,899 dengan tingkat signifikansinya sebesar 0,026 yang ternyata lebih kecil dari tingkat signifikansi yang digunakan yaitu sebesar 5\% $(0,05)$ atau $0,026<0,05$ Hal ini berarti $\mathrm{H}_{1}$ diterima, yang artinya Good Corporate Governance berpengaruh signifikan terhadap Profitability (ROE).

Pada Tabel 4.3 dapat dilihat nilai koefisien korelasi (R) adalah sebesar 0,249. Hal ini menunjukkan bahwa variabel bebas yaitu Good Corporate Governance mempunyai hubungan yang lemah positif terhadap Profitability (ROE).

Hasil perhitungan koefisien determinasi dalam penelitian ini dapat dilihat pada Tabel 4.3.tampak bahwa nilai koefisien determinasi adalah 0,062. Hal ini menunjukkan bahwa besarnya pengaruh variabel bebas, yaitu Good Corporate Governance terhadap variabel terikat yaitu Profitability(ROE) yang dapat diterangkan oleh model persamaan dalam penelitian ini adalah sebesar $6,2 \%$, sedangkan sisanya sebesar $93,8 \%$ diterangkan oleh faktorfaktor lain yang tidak dimasukkan dalam model regresi ini.

\subsection{Pembahasan}

Hasil pengujian hipotesis yang telah dilakukan maka, diketahui bahwa $G C G$ memiliki pengaruh positif yang signifikan terhadap indikator profitabilitas dalam perusahaanperusahaan sektor perbankan yaitu $R O E$ hal ini menunjukkan bahwa semakin baik $G C G$ maka akan semakin meningkat tingkat profitabilitas. Penerapan $G C G$ yang telah diwajibkan oleh Bank Indonesia mengharuskan perbankan di Indonesia mengelola bisnis mereka secara baik. Semakin baik penerapan $G C G$ maka akan makin meningkat kemampuan perusahaan dalam menghasilkan laba. Hal ini mendukung penelitian Tjondro dan Wilopo (2011) yang menyatakan bahwa dengan penerapan $G C G$ akan meningkatkan kinerja perusahaan secara positif karena proses pengambilan keputusan akan berlangsung secara lebih baik sehingga akan menghasilkan keputusan yang optimal, dapat meningkatkan efisiensi serta terciptanya budaya kerja yang lebih sehat.

Penelitian ini juga mendukung hasil penelitian Premuroso dan Bhattacharaya (2007) dalam Tjondro dan Wilopo (2011) menunjukkan bahwa rasio-rasio yang mampu mewakili profitabilitas perusahaan seperti $R O A, R O E$ dan NIM memiliki hubungan positif signifikan dengan $G C G$.

\section{PENUTUP}

\subsection{Kesimpulan}

Berdasarkan hasil uji regresi linier sederhana dan uji hipotesis serta pembahasan yang telah diuraikan, maka dapat ditarik kesimpulan penelitian bahwa, $G C G$ memiliki pengaruh yang positif signifikan terhadap profitabilitas perusahaan perbankan. Hal ini berarti semakin baik penerapan $G C G$ maka akan makin meningkat kemampuan perusahaan dalam menghasilkan laba yang dalam hal ini diukur dengan $R O E$.

\subsection{Saran}

Berdasarkan hasil penelitian yang telah dilakukan ini, peneliti dapat memberikan saran sebagai acuan bagi pihak yang berkepentingan:

1. Bagi Investor

Bagi para investor yang akan melakukan investasi pada perusahaan, lebih baik memilih perusahaan yang memiliki skor $G C G$ yang tinggi, karena skor penerapan $G C G$ pada 
perusahaan mempengaruhi kinerja keuangan perusahaan. Hal ini telah terbukti dalam penelitian ini semakin baik rasio perusahaan maka semakin tinggi pula skor penerapan $G C G$ perusahaan tersebut.

2. Bagi Manajemen Perusahaan

Dari hasil peneitian ini, hendaknya manajemen perusahaan menjadi lebih termotivasi untuk menerapkan GCG secara konsisten agar membantu meningkatkan kinerja keuangan perusahaan.

\section{DAFTAR PUSTAKA}

Bank Indonesia. 2006. Peraturan Bank Indonesia Nomor 8/4/PBI/2006 Tentang Pelaksanaan Good Corporate Governance Bagi Bank Umum. (online), (www.bi.go.id, diakses pada 16 April 2014).

Bank Indonesia. 2006. Peraturan Bank Indonesia Nomor 8/14/PBI/2006 Perubahan Peraturan Bank Indonesia Nomor 8/4/PBI/2006 Tentang Pelaksanaan Good Corporate Governance Bagi Bank Umum. (online), (www.bi.go.id, diakses pada 16 April 2014).

Bank Indonesia. 2013. Peraturan Bank Indonesia Nomor 15/15/DPNP/2013 Tentang Pelaksanaan Good Corporate Governance Bagi Bank Umum. (online), (www.bi.go.id, diakses pada 16 April 2014).

Daniri, Mas. 2005. Good Corporate Governance Konsep dan Penerapannya Dalam Konsep Indonesia. Ray Indonesia, Jakarta.

Dani Riandi dan Hasan Sakti Siregar. 2011. Pengaruh Penerapan Good corporate Governance terhadap ROA, NPM dan EPS pada Perusahaan yang Terdaftar di CGPI. Jurnal Ekonomi Volume 14 Nomor 3.

David Tjondro dan Wilopo, R. 2011. Pengaruh Good Corporate Governance (GCG) Terhadap Profitabilitas dan Kinerja Saham Perusahaan Perbankan yang Tercatat di Bursa Efek Indonesia. Journal of business \& banking.

Emirzon,Joni.2007. Prinsip-Prinsip Good Corporate Governance : Paradigma Baru Dalam Praktik Bisnis Indonesia. Yogyakarta: Genta Press.

FCGI, 2001. Corporate Governance: Tata Kelola Perusahaan. Edisi Ketiga, Jakarta.

Ghozali, Imam, 2006. Aplikasi Analisis Multivariat dengan Program SPSS. Cetakan Ke IV, Badan Penerbit Universitas Diponegoro, Semarang.

Hanafi, Mamdah M dan Abdul Halim, Analisa Laporan Keuangan, Edisi Pertama, UPP AMP YKPN, 2005.

Http://www.bpkp.go.id. ditelusuri pada tanggal 10 Mei 2014.

IDX. Laporan Tahunan Publikasi. www.idx.co.id diakses 10 Mei 2014. Manado.

Indah Sulistiyowati, Ratna Anggraini, dan Tri Hastuti Utaminingtyas. 2010. "Pengaruh Profitabilitas, Leverage, dan Growth terhadap Kebijakan Deviden dengan Good Corporate Governance sebagai Variabel Intervening". Simposium Nasional Akuntansi 


\section{AKMEN-35.}

Johan Wahyudi. 2010. "Pengaruh Pengungkapa Good Corporate Governance,Ukuran Dewan Komisaris Dan Tingkat Cross-Directorship Dewan Terhadap Nilai Perusahaan". Skripsi. Universitas Diponegoro.

Komite Nasional Kebijakan Governance. 2006. Pedoman Umum Good Corporate Governance. Jakarta. KNKG

Lukman Dendawijaya. 2009. Manajemen Perbankan. Jakarta. Ghalia Indonesia

Nasution, Marihot dan Doddy Setiawan. 2007. Pengaruh Corporate Governance terhadap Manajemen Laba di Industri Perbankan Indonesia. Simposium Nasional Akuntansi X. Makassar 26-28 Juli 2007.

Purwantini, V.T. 2011. Pengaruh Mekanisme Good Corporate Governance Terhadap Nilai Perusahaan dan Kinerja Keuangan Perusahaan yang Terdaftar di Bursa Efek Indonesia. Jurnal Ekonomi Bisnis dan Perbankan, 19(19), STIE AUB, Surakarta.

Premuroso, Ronald F. dan Somnath Bhattacharya. 2007. "Is There a Relationship between Firm Performance, Corporate Governance, And a Firms Decision to Form a Technology Committee?”. Journal Compilation. Vol. 15. No. 6. p. 1260 - 1276.

Retno, R.D., Printinah, D. 2012. Pengaruh Good Corporate Governance dan Pengungkapan Corporate Social Responsibility terhadap Nilai Perusahaan yang Terdaftar Di Bursa Efek Indonesia Periode 2007-2010. Jurnal Nominal, 1(1).

Suad Husnan \& Pudjiastuti, Enny. 2007. Dasar-dasar Manajemen Keuangan. Yogyakarta : UPP AMP YKPM.

Zarkasyi, Moh. Wahyudi. 2008. Good Corporate Governance. Alfabeta. Bandung. 